\title{
Community Development and Corporate Social Responsibility: A Case Study of Mining Companies in Zvishavane and Mutoko in Zimbabwe
}

\author{
Charles Dziro \\ Lecturer, University of Zimbabwe-School of Social Work
}

\begin{abstract}
The research attempted to find the relevance of community development and corporate social responsibility in the work of indigenisation and empowerment programmes in Zimbabwe. The study was therefore carried out in two different Districts where mining companies operate. The study employed a qualitative method in collecting data. The study then find out that corporate social responsibility is influenced by the desire to make profits and not by the philanthropic need to assist communities in their economic, social and environmental development. The research noted the need for Government to introduce mechanisms that help mining companies to use some of their profits to improve local communities like community share ownership schemes in a transparent and accountable manner to ensure that all citizens benefit despite individuals' political and economic affiliations. This could happen through recruitment of locals with appropriate skills to avert the problems of unemployment, to motivate companies to procure some items which can be found locally as part of promoting community development as this would assist locals to improve on their lives. One of the mechanisms would be to adhere to the requirements of the indigenisation and Empowerment Act with some amendments to accommodate all stakeholders making it an all encompassing piece of legislation which does not discriminate on colour, political affiliation, race or place of origin.
\end{abstract}

Key words: Community, Development, Corporate, Social, Responsibility, Indigenisation, Zimbabwe

\section{Introduction}

Zimbabwe is one of the African countries located in the Southern African Development community (SADC) with a total population of 12973808 as at 18 August 2012 (ZimStat 2012). Zimbabwe is divided into twelve Provinces. Zvishavane is found in the Midlands Province and Mutoko is located in Mashonaland East Province. Midlands Province has a total of 1622476 including Zvishavane Rural population which is about $10 \%$ of the total population. Zvishavane has a total population of 70047 people. Mutoko has a population of 145676. Both Districts are characterised by low rainfall whilst people in Mutoko survive on the sale of vegetables and tomatoes grown from their small gardens and people in Zvishavane survive through alluvial gold panning where they are popularly known as makorokoza. The country's economy is on a nose dive following the disputed land redistribution programme in 2000 which saw an exodus of white farmers leaving the country for neighbouring countries. Shortages in basic commodities after many companies closed down saw the country relying on imports. Therefore, the remaining companies need to be lured to assist local communities in their desires to develop. This can be possible if the available companies would commit their resources through their corporate social responsibility to help in community development.

The concept of community development is a process which is conducted by community members in promoting their communities as a group. It is a process where local people cannot only create jobs, income and infrastructure development but also help their community to become fundamentally better able to manage social change (Hasenfeld 2010).

Such benefits of community development as employment and infrastructure development come through local people changing their attitudes, mobilising existing skills, improving networks, thinking differently about problems and using community assets in new ways (Shaffer et al 2004). Community development, therefore, improves the situation of a community not just socially and economically but also as a strong functioning community itself. This can be possible through efforts from community members themselves and also from external efforts which are prepared to assist communities to develop from one point to the next.

A community is a group of people with a shared identity, hence, community development relies on the innovative interactions between these people and joint action rather than individual activity, what some Sociologists call 'collective agency' (Flora and Flora 1993, Bradshaw 2003).

Development is a process that increases choices. It means new options, diversification, thinking about apparent issues differently and anticipating change. Development then involves change, improvement and 
vitality. It is a directed attempt to improve participation, equity, flexibility and the quality of life. (Bradshaw, 2003, Christenson and Robinson, 1989)

Therefore, bringing the two concepts together, means that a community itself engages in a process aimed at improving the social, economic and environmental situation of the community in creating development for itself. This means that the community is both the means and the end of community development. The community itself takes action and participates together. It is through this action that the community becomes more vital not just economically and socially but as a strong functioning community in itself. The United Nations defines community development as a process whereby the efforts of government are united with those of the people to improve the social, cultural and economic conditions in communities. Effective community development therefore requires the participation of those who represent various interests and the willingness of government to form partnerships with groups. Tan (2009) notes that Clinicians and other workers trained from the Community development perspective often cite this anonymous Chinese poem to summarise their work and the goals they have for change:

\title{
II. Serving the People
}

\author{
Go to the people \\ Live among them \\ Learn from them \\ Love them \\ Start with what they have \\ Build on what they have \\ But of the best leaders \\ When their task is accomplished \\ Their work is done \\ The people all remark \\ 'We have done it ourselves'
}

(Anonymous, as cited in Gordon, 1995, 87)

This serves to show that community development is not just an activity but a process that is continuous, guided and adheres to a set of general principles. In some cases, communities need external support from outsiders for the process of development to move through. Therefore organisations, in the form of companies, provide external support to communities through their corporate social responsibility and at the end of development it is the community which benefits.

The concept of corporate social responsibility is based on the argument that business is sanctioned and promoted by society. Society legitimates business by allowing it to function and to use the scarce resources available locally (Maphosa, 1997). It should be noted that corporate social responsibility is a business process that a company adopts beyond its legal obligations in order to create added economic, social and environmental value to society and to minimize potential adverse effects from business activities and includes interactions with suppliers, employees, consumers and communities in general. This is a commitment to contribute to sustainable economic development, working with employees, their families, the local community and society at large to improve their quality of life, in ways that are good for business and for community development. Society then expects business to refrain from activities that have a negative social impact such as pollution, discrimination and exposing communities to hazardous conditions. Society also provides an environment for business to earn profit, (Maphosa, 1998).

The purpose of this paper is therefore to demonstrate that corporate responsibility as a company programme, should be selected, designed and implemented in response to community's needs and not through corporate organisations' needs to meet the developmental needs of the community.

\section{Corporate Social Responsibility in Zimbabwe}

A look at mining history in Zimbabwe reveals that mining has been instrumental in the development of communities in rural areas. The many towns that have developed around mining in Zimbabwe, for instance, Hwange, Kadoma,, Shurugwi, Zvishavane , Bindura and Bulawayo among others is a clear testimony to what is achievable if mines have a desire and are encouraged and incentivized to do more corporate responsibility which can result in community development. The development of these centres took place as a desire for the responsible entities willing to cooperate.

Besides the high risk noted in the country of late, there are other policy and legislative arrears that are keeping investors at bay making corporate social responsibility a little bit difficult. These include questions about the implementation of the Indigenisation and Economic Empowerment Act and the archaic and colonial piece of legislation, Mines and Minerals Act (Chapter 21:05). In his address to the $71^{\text {st }}$ Chamber of Mines of 
Zimbabwe Annual General Meeting, President Robert Mugabe tried to give clarity on the key question of Indigenisation and Economic Empowerment Act that the law was not about expropriation or nationalisation, but that it is intended to generate the goodwill to allow more participation by Zimbabweans and that whatever equity is disposed, would be in exchange for a fair price. The idea was to talk in a way which does not scare away investors in the country. The Newsday of 16 December 2013 gave a list of 19 companies that have not subjected themselves to the dictates of the Indigenisation and Empowerment Act citing implementation irregularities within the Act.

Most governments try to strike a balance between government and investor revenue needs by a 'fair and equitable' system (Otto, 2000). Unfortunately, no one has been able to determine what an ideal fair and equitable system is. Another approach is to see if the fiscal system is competitive, that is, using the market as a proxy to determine whether a system is fair. In today's global economy, multinational companies have many countries to choose from, and a low tax country is generally preferred by an investor to a high tax country. The tax is meant to cushion locals of their minerals extracted and to improve their livelihoods thereby catering for corporate social responsibility. In the Zimbabwean situation, most of the giving by multinational companies is not out of charity but a lot of corporate giving is out of mere profits (Maphosa, 1998).

Zimbabwe has a significant and diverse mineral resource base. The Zimbabwe Geological Survey of 1990 lists no fewer than 66 base and industrial mineral deposits in the country. It is estimated that there are 40 mineral deposits which are being exploited currently in Zimbabwe. These include gold, coal, iron ore, black granite, emeralds and lithium. According to the Zimplats news letter 2010, Zimbabwe has the second largest reserves of platinum in the world after South Africa.

The significant and diverse mineral resource base for Zimbabwe represents a comparative advantage which might not necessarily be a competitive advantage for the country.

The following table shows a projection of the mineral growth rate in Zimbabwe as from 2011-2015

\begin{tabular}{|l|l|l|l|l|l|}
\hline Mineral & 2011 & 2012 & 2013 & 2014 & 2015 \\
\hline Gold/kg & 13000 & 15000 & 18000 & 21000 & 25000 \\
\hline Nickel/t & 7675 & 8842 & 10611 & 12733 & 15279 \\
\hline Coal/t & 300000 & 6360000 & 7147000 & 7146000 & 7146000 \\
\hline Asbestos/t & 2100 & 2100 & 2100 & 2100 & 2100 \\
\hline Chrome/t & 610000 & 700000 & 700000 & 700000 & 700000 \\
\hline Platinum/kg & 12000 & 13287 & 15751 & 19721 & 19666 \\
\hline Palladium/kg & 9600 & 10630 & 12601 & 15776 & 15732 \\
\hline Black granite/t & 168000 & 170811 & 173748 & 176602 & 179511 \\
\hline Diamonds (caratas) & 8065651 & 12111867 & 14837707 & 18443797 \\
\hline Growth Rate & $44 \%$ & $20 \%$ & $18 \%$ & $19.4 \%$ & 21463054 \\
\hline
\end{tabular}

Source: Ministry Economic Planning and Investment Promotion, Reserve Bank of Zimbabwe, Ministry of Finance 2013

Zimbabwe has been exporting thousands of tones of the black stones popularly known as 'black gold' to both developing and developed countries. The Financial Gazette May 2010 notes that to date, eleven companies, (two foreign owned, four locally owned, and five partnerships) are quarrying for black gold in Mutoko. According to the Minerals Marketing Corporation in Zimbabwe (MMCZ), 98\% of the mined granite is exported to Italy, South Africa, Germany, Spain, United Kingdom, China, Japan, Malaysia, Singapore, Argentina, the United States and Canada. Italy consumes about $70 \%$ of the exports.

The Financial Gazette of 13 to 19 May 2010 also confirmed that granite sales for 2009 were 162413 metric tonnes (mt) valued at US\$16 127000 compared to $162000 \mathrm{mt}$ valued at US\$16 168000 sold in 2008.

\section{Methodology}

The study used the qualitative approach and used the following tools for data gathering:

\section{Focused Group Discussions (FGDs)}

Six Focus Group Discussions (FGDs) with the help of a FGD guide were carried out with men and women between the ages of 20 to 80 years. Age cohorts $(20-40,41-61,71-80)$ were used for the selection of respondents. Each FGD had 6 people and was also based on willingness to participate. Three FGDs were carried out with men and three FGDs were carried out with women. The total number of people who participated was therefore 18 people in Zvishavane and 18 people in Mutoko. Since FGDs are basically exploratory, it was necessary to get an indication of what people perceive as community development. The FGDs also provided data on what the community and companies perceived as corporate social responsibility. 


\section{Key informant Interviews (KII)}

Nine key informant interviews were undertaken using key informant interview guides. The key informants included traditional leaders, health officials, an education official, a local government official, indigenisation and economic empowerment ministry official and mining company management official. The key informants included both males and females. The key informants were interviewed because they were well connected and informed community experts. The experts had localised and developmentally appropriate firsthand knowledge and the nature of corporate social responsibility programme meant for community development. They also provided confidential incidences, statistics and conditions that explain implementation problems in their community with regard to developmental issues which would require external assistance.

\section{In-depth Interviews (IDIs)}

A total of 10 in-depth interviews were conducted by the author of this paper using an in-depth interview guide. Men and women aged 20-80 years were interviewed. The respondents were community members and mine employees. Purposive sampling technique was used for the selection of respondents. Indepth interviews helped to solicit information about personal experiences, perspectives and attitudes of the community towards community development and corporate social responsibility.

The methodology enabled the study to obtain real life experiences of both the key informants and the communities themselves.

Interviews with community individual members focused on how they perceived their everyday lives as they dealt with the local mining companies with respect to community development and corporate social responsibility and their future when mining companies leave the country. Translation of open ended questions from English into vernacular, Shona, allowed for improved participation of informants not conversant with English.

Data collection was organised through group interviews (Denscombe, 2010) to obtain group perceptions on the subject. Efforts were made to maintain confidentiality (Hussey and Hussey, 1997). Prior consent was sought from ministry of health, ministry education, local government, and mining companies' management, political and traditional leadership and from respondents themselves.

\section{Study Findings}

The FGDs in Zvishavane revealed that when the mine was undertaken, communities were moved to a new site, a farm which was bought by the Mining Company. One respondent noted:

"We were notified of the new development through our traditional and political leadership that we were to be moved to one site identified by the company on our behalf. We had no objection to that as we needed land for farming".

Part of the local population had to be relocated at the onset of the extraction of the minerals. The mine management alleged that a full inventory of household movable and immovable assets was undertaken. A comprehensive resettlement and rehabilitation plan was developed with the participation of the affected households. The rest of the community was also consulted and was incorporated into the resettlement plan. Mine management noted that graves in the mine site were exhumed in full consultation with the relatives of the dead and traditional chiefs though some members were not happy with the idea of grave exhumation.

For some who did not leave with the rest of the members, their relatives' graves were not exhumed. Those who agreed had some objection but did not refuse out rightly as they felt they were caught in between. One member noted:

"We were not happy that our relatives' graves were exhumed as this was not in accordance with our tradition. We were only informed very late of the process and we only agreed because we desperately needed land both for our animals to graze and for our growing children to farm".

One mine management employee revealed that;

"the relocation and rehabilitation programme were in a systematic and consistent way in full alignment with the existing World Bank operating policy on involuntary resettlement. The model is regarded within Zimbabwe as a model of corporate social responsibility as the company took responsibility".

The company felt it was their leading practice.

Focus group discussions conducted for those who were relocated willingly expressed that the operation at the mine was carried out positively and received benefits from the mine. One member from the focus group discussion remarked by saying:

"efforts by the mine to provide us with the basics has been commendable".

This was a different story from the understanding of the workers of both Zvishavane and Mutoko companies. One employee respondent noted that:

"despite all the efforts we put in extracting the minerals, we are getting little in terms of remunerations for our sweat". 
There were some members of the community who could not manage to leave with the rest for the resettlement because they felt they could not move to the new site leaving their ancestors' graves. Zimbabwean society has some traditional members who still believe that the dead have a full control of the living. One member commented,

"I believe, like any other believer that if I do not respect those who departed, I might have some misfortunes befalling on whatever I do or wherever I go".

It is this group which did not leave with the rest of the people. The mine had to make sure they benefited though there were some incidences of conflict with this local group as most of their grazing areas were occupied by the mine. As one member of the community commented that:

"our animals no longer enjoy the benefits of good pasture we used to have as our animals are experiencing overgrazing as most of the land was taken over by the mine. Most of the land has been fenced and water for our animals has been polluted".

There were complaints from those who were resettled as there were experiences of some people who were 'invading' them. One member from the resettled community noted:

"Within the resettlement programme, there were unauthorised and uncontrolled migration and occupation of common grazing areas by illegal settlers and their livestock had to compete for pasture thereby creating a threat to the good resettlement programme which was created for them".

Land in Zimbabwe has been a preserve of the few minorities who were whites before independence in April 1980. These people owned large tracks of land at the expense of the majority of black natives (Tauyanago et al 2009). So when some community members realised that their other colleagues had been resettled through the support of the mining company, and were relocated to good fertile land, they had to create opportunities for themselves to some areas where they felt they could benefit as well. They provided themselves with pieces of land where the properly resettled people were using as their grazing area for their animals. Complains to the local traditional and political leadership did not yield anything fruitful. The mining company in Zvishavane had handed over the resettled community to Government soon after people were resettled.

Lack of financial resources in the country, due to the economic melt-down since 2000 (Kanyenze et al 2011), led Government to fail to maintain community infrastructure like boreholes, schools and supply of drugs for the good health centre constructed by the mining company in Zvishavane as one individual member noted:

"We never thought all things will fall apart like this as the infrastructure constructed by the mining company for the resettled community could be seen to fail to function properly. Of the 17 boreholes drilled, only 5 are functioning and the rest have not been repaired. The clinic does not have drugs. Enrolment at the school has gone down leading some parents taking their children to stay with relatives outside the resettlement scheme."

A key informant from Ministry of Education noted that:

"It is the responsibility of parents and their school development committee to make sure development is taking place at their school and Government only come in as a referee where there are conflicts."

Some challenges were also experienced in Mutoko. All FGDs noted that communities around the mining operations were still yet to benefit from the extraction of their resources. Mining companies did not supply anything to the community. As one community member from one FGD commented,

'the community need boreholes as dams are silting and not even one mining company has offered a bulldozer to scoop the sand from our dams locally'.

This was made as reference to heavy siltation of one of the oldest dam built by Missionaries in 1969 to supply water to two schools and the surrounding community.

The Zvishavane mining company established a variety of mechanisms to both inform and exchange information with stakeholders and communities. Consultation procedures have been formalised and meetings were scheduled on a regular basis. One of the FGDs in Zvishavane commented that:

"each village has its own community liaison committee though the liaison committee mechanism may not be as effective and representative as originally intended and the 'committee' approach may need to be modified or additional communication and consultation modes need to be established. This will be especially important as engagement expands to additional communities and other stakeholders".

The community around the Zvishavane mine conducted meetings with regard to the existence of the mine within their surroundings. Minutes of community meetings were kept by the communities themselves but as handwritten notes. The agreement on employment of workers within the mine had reached some levels of misunderstanding. Local recruitment and hiring policies and practices have become a sore point within the surrounding communities and needed to be improved for both Zvishavane and Mutoko mining companies and the local communities' mutual benefit. In Zvishavane, management of the company noted that:

"we have been pro-active in promoting the development and contracting of local businesses and recruitment of locals but more can still be done". 
Some FGDs held in the Zvishavane mine raised issues of corruption and non-transparency by the company as one commended:

"most of the contracts to provide services were given to companies in South Africa and not in Zimbabwe. Even the supply of vegetables and tomatoes to the company were contracted to companies in Harare and not to locals we suspect it might be because locals cannot afford to pay bribes to company officials responsible for tenders".

In as much as they raised these complains locals in Zvishavane were happy in the construction of schools and refurbishment of health facilities which were carried out by local individuals companies who were chosen from the community, tapping from local skills as they noted:

"the only thing happening is the selection of the construction and refurbishment of schools and health clinics. Otherwise it might be because they exploit on cheap labour".

FGDs in Mutoko were suspecting that there was corruption between the mining companies and local leadership in which they accused the leadership of allowing community resources to be siphoned outside the country for the benefit of other countries. All FGDs noted:

"We believe the signing of mining contracts with the mining companies is not properly done leading to our resources taken outside the country without the benefit of locals especially those companies mining the black granite".

Training and skills development of local people was observed to be the weakest part of the community assistance programme. One key informant commented:

"recruitment of professionals and training is done outside the mine and we have been expecting our children who are also professionals and those able bodied to be recruited to do manual jobs within the mine".

Locals felt the methods used by companies to employ workers discriminate against locals because companies felt locals were not skilled to fit into the jobs available. They advocated for employment of locals in doing manual jobs which do not require any specialities

'What speciality does one need to cut all grass?' one community member commented on the recruitment of outsiders in cutting grass within the mining environment.

The introduction of the Indigenisation and Empowerment Act should help improve the welfare of communities. Locals should benefit more than 'outsiders'. One key informant put the blame on the old Mines and Minerals Act which he believed needs to be revisited as he noted:

"we cannot win the battle as mining companies are taking advantage of the old Mines and Minerals Act which has not been amended to meet the current economic changes. They also take advantage of the poorly negotiated contracts and policies regarding the extraction of minerals in the country. We hope the Indigenisation and Empowerment Act will be to our advantage."

Both FGDS in Mutoko and Zvishavane noted the need for transparency in the community share ownership trust and that all citizens should benefit despite their political and economic status. One respondent noted that;

"the community ownership schemes have come as a blessing to all citizens especially this period when everyone need government intervention for those who stay closer to the mining companies but it is only those who have the political muscle or economic links that benefit from the community share ownership schemes".

\section{Agricultural support}

The FGDs from Zvishavane noted that a good dip tank was constructed by the mine for the community:

"we used to travel twenty-five kilometres to the nearest dip tank with our cattle. The dip tank has brought a direct befit to the community as we now dip our animals and protect them against animal related diseases".

Farm training programmes have been provided by the Zvishavane mining company, in which farmers in the resettlement programme were trained to vaccinate their cattle against diseases without the assistance of government veterinary officers before the resettlement was handed over to Government. One respondent noted;

"I feel very much supported as I can now vaccinate my animals without a veterinary officer around. Our animals cannot die because there is no veterinary officer in our community. We can vaccinate our animals whenever we feel there is that need".

The Zvishavane company boosted the local livelihood by improving the quality of cattle stock in the resettlement area by cross breeding pure breed Braham bulls with the indigenous herd. One respondent note;

"the company donated twenty-five pedigree bulls and thirty-seven heifers to boost the quality of our animals. Those who were left behind at the mine were provided with fertilisers and agricultural inputs like maize seeds and sorghum for each season". 


\section{Support to Health care Needs}

A health care centre was constructed by the mine in Zvishavane in partnership with the local community and Ministry of Health. One key informant noted that:

"we are pleased that a good health care centre was built by the mine for locals and another clinic was also refurbished and piped water was connected. Good roads linking to the health centres have been improved for ease access to them. What made all these efforts meaningless was lack of qualified staff to work in these structures."

This was echoed by one respondent who noted:

"the health needs of the community are paramount but have been affected by lack of qualified staff to work in the area and shortage of drugs. These structures will end up being white elephants within the community".

The FGDs called on the mine to intervene by recruiting and provide salaries for nurses in the local clinics.

"The recruitment of nurses by the mine for the community would mean that the mine would provide such basics and that the community would see a direct benefit of the existence of the mine leading to community development rather than leaving everything to government which is also facing challenges".

\section{Support to Education}

In partnership with other local organisations, most dilapidated classroom blocks have been demolished and the respective schools have been given a new lease of life by the Zvishavane mining company as one mine Community Relations Manger commented.

'The provision of improved learning environments, including the construction of new classrooms, the supply of furniture and text books, teacher refresher courses and improved school administration, remain an important focus of the company's educational development activities."

The Zvishavane Company improved educational resources in the area surrounding its operations by providing children in the area with text books in English, mathematics and science. Getting information from the Zvishavane mining company, by 2007, the mining community was one of the few rural communities in Zimbabwe that had a one-to-one child to book ratio in the three core subjects. Though this might not be considered enough, one respondent in Zvishavane noted that:

"the mining company has done something good to the local communities which must be emulated by all mining concerns in the country as a form of corporate social responsibility. This would increase the pace of community development throughout the country where such companies are located".

This scenario was a different Mutoko. One respondent from the community in Mutoko noted that:

"when a transformer supplying electricity to our local business centre was vandalized, we received no help from the granite miners though we submitted our request. They also find it difficult to repair the road they use in taking the minerals outside the country. Even the construction of classroom blocks or clinics has not been carried out by these companies".

The Government is receiving very little from granite. One key informant noted that:

"the Government is receiving two percent in the form of royalties every year from mining companies. The Rural District Council, where the mineral is mined, has no control over mining of the vast resource because the Government transferred its control to the Ministry of Mines and Mining Development which collects royalties through the Minerals and Marketing Company of Zimbabwe (MMCZ) which is the country's sole marketing agent for minerals".

Another key informant from the Rural District Council in Mutoko noted:

"the Rural District Council charge development levy from Miners to get some form of reward for owning the resource. Miners resisted for years to pay the levy in full. This is a true sign of mining companies refusing to honour their social responsibility to the community."

\section{Discussion}

The study observed that mining companies in Zvishavane provided their corporate social responsibility where they had a comparative advantage. This is consistent with findings by Maphosa (1998) who observed that companies are in business for profit. Their support to the resettled farmers in this study just ceased by the time they completed the resettlement programme. They were much into assisting those around the mining environment in which they helped in the construction and refurbishment of clinics and schools was carried out. They also electrified the clinics and provided books and furniture to local schools. The idea behind otherwise was to make sure they assist communities such that they would not be disturbed as they concentrate on their mining ventures. It would be difficult to explain the situation in Mutoko. 
The mining company in Zvishavane provided services to communities which saved as a direct benefit to locals as compared to mining companies in Mutoko who were interested in extracting minerals to their benefit and never maintained even the roads they used to ferry the products they procured. The findings were consistent with the findings by Gibbon et al (2000) that society experts these business organisations to be good citizens obeying laws and refrain from activities that have negative social impact such as pollution, discrimination and exposing communities to hazardous conditions. This could be an indication that the contracts were signed with different conditions for the two mining companies. Mining companies in Mutoko showed no signs of wanting to develop local communities but to exploit them. The companies in Mutoko were taking advantage of the piece of legislation that should guide the mining of minerals, the Mines and Minerals Act that does not provide any suggestions to the effect that mining companies should provide services to locals where they extract minerals. This could help avoid any conflict with local communities as was the case in Nigeria where communities ended up accusing Government of siding with mining companies in corruptive deals. As one key informant suggested, local authorities should be given the mandate to charge levies through an Act of parliament and allowed to use the same monies to develop local communities. The full participation of local communities should then be enhanced through policies to promote accountability and transparency. The Government should come up with policies which safeguard the interest of locals and thereby promote community development. The Government should make sure information with regard to the mining rights is disclosed to communities such that locals do not have any suspicion on how these mining companies are operating. It is very correct that without access to information, it becomes impossible to hold any individuals, communities, institutions, companies and even Government, accountable. Therefore, there is need to amend the Mines and Minerals Act (1976) which has become an archaic and invalid piece of legislation aligning it with the new constitution (2013) and the Indigenisation and Empowerment Act (2007). Development of communities cannot take place when communities themselves lack resources and even initiative to develop. The newly introduced indigenisation policy in Zimbabwe should act as a safeguard for locals in terms of developing their community. The indigenization policy should empower communities by allowing mining companies and any other foreign owned organization to assist locals to develop by providing them with resources. Just like the Black Economic Empowerment (BEE) in South Africa (Sachs, 2007), the Indigenisation policy should be seen to promote integrity and ubuntu (humanness) as well as a culture of dialogue to reach a common understanding about what needs to be achieved and how. The policy should support investor confidence in the country by being certain, clear and consistency in its application. The policy should promote a value of social conscience that invites every Zimbabwean to consider whether the way resources are being distributed will be sustainable. The policy should also demonstrate the value of contributing towards improving quality of life of the less fortunate communities. It should act as a sense of shared destiny and a shared understanding of what the current generation in Zimbabwe want to leave behind. The minds of every Zimbabwean should simply note that political freedom without economic rights will ultimately lead to a civil uprising. The introduction of community share ownership schemes by Government, which are meant to improve the welfare of indigenous people, will go a long way in the improvement of communities where mining companies are operating. These ownership schemes should allow transparency and accountability to dominate such that every Zimbabwean citizen is benefiting without any political or economic connections.

Projections of the growth rate of mining industry in Zimbabwe by the Ministry of Finance and the Reserve Bank of Zimbabwe in 2013 indicate that by 2015, the growth rate will be at $8 \%$ from a projected $19.4 \%$ in 2014. The fact of the matter is that investors will have less interest in the economy as 19 foreign owned companies (Newsday 16 December 2013) are citing inconsistencies in the Indigenisation and Economic Empowerment Act and are yet to comply with its requirements. The bone of contention being that foreign owned companies should shade off $51 \%$ of their shares to black indigenous people. The truth of the matter is that blacks should work for the shares and not to be 'given' unto them.

It will be an advantage to local people if job opportunities which arise within the mining companies would be taken over by locals in a transparent manner for both short term and long term vacant positions. This is important given the claim that there are skilled people in the community with skills to man permanent positions. The mining companies should have a community skills register in which all the skilled and unskilled individuals are registered locally. This will help to manage mistrust and suspicion which is normally based on lack of information. This should also be updated periodically to find out if there are locals with skills incorporating not only current residents but also qualified family members who may be working or studying elsewhere. There is need to come up with village liaison committees whose duties should be expanded to include validation of the original residency status of returning citizens who may be qualified to apply for more skilled positions within the mining community. Mining companies should adopt policies to recruit local students studying at higher institutions of learning as interns. This would enable a better assessment of aptitude for full time employment.

Mining companies should employ qualified personnel to work in their community services department like social workers. These professionals should then work as liaison officers between the companies and the 
surrounding communities. Social work is a profession of many faces. Therefore, companies can improve their community image by engaging such professionals.

Mining companies should have a respect for traditional values and cultural heritage as this will make both the company and community to have a mutual respect for each other. The mining company in Zvishavane managed to respect the graves for those who left the mining site to resettle themselves in the new areas. Graves were exhumed in respect to the requests of the relatives and were reburied closer to them.

The government of Zimbabwe should introduce payment of royalties through Rural District Councils so that multinational companies improve the social and economic community development needs of the communities where they operate from. These royalties, for multinational companies, should be charged at international competitive level rates. The monies will then be directed towards community development. The Indigenisation and Economic Empowerment Act or the Mines and Minerals Act should provide a close where each mining company, operating in Zimbabwe, should help local communities, through corporate social responsibilities, to develop. This is consistent with what Moyo (1999) noted in Botwsana that the Government enacted a legislation on the licensing of prospective miners. This will help to have a thorough screening of prospective miners. The received fund should be directed at the communities close to the mines saving as a stopgap measure on the disadvantages the communities might be experiencing.

With the introduction of the Indigenisation Act, corporate social responsibility should be legalised by government as a way of encouraging community development to local communities by mining companies operating within their environments. The direct introduction of legalised corporate social responsibility will assist the less fortunate members of the society to develop as community projects will be funded for the benefit of all members.

Mining companies should also consider their workforce whom they use to extract the minerals. This is the ultimate resource for any business organisation. These companies should have a fair remuneration (which is consistent with the current cost of living), ensuring healthy, safe and pleasant working environments, democratising the workplace by encouraging worker participation in ownership and decision making at all levels of the organisation and providing social services such as education and health for workers and their families. The introduction of employee share ownership schemes will also go a long way if properly carried out in a transparent and accountable manner in helping company employees in quest for ownership of company resources. A corporate social responsibility should not be alien, illegitimate, exploitative or mysterious to the social context within which mining companies operate. The idea should be complementary. That is, communities should benefit from the resources extracted from their soils whilst companies should benefit from the minerals they extract. There is an indispensability of interdependence between the two entities. Goods, services and experiences should be shared transparently. The mining companies come from different countries. Therefore, sharing of information on community development without exploiting one another will benefit both sides. Community development through corporate social responsibility will help in the eradication of poverty as this will accrue to sustainable development. The process of community development will not be characterised by non-regression but progression to superior ranks that is, from highly indebted poor communities to low income and from low income to middle income and from middle income to high income communities and from high income to advanced communities.

\section{Acknowledgements}

The researcher would like to express his gratitude to all respondents who participated as individuals, in Focus Groups and all the key informants and those mine employees and their management and other members of the community who have unfailingly offered me the most courteous assistance and been unstintingly generous with their time and information. I remain responsible for the analysis and assessments contained in this document.

\section{References}

[1] Bradshaw, T.K (2003) Complex community Development Projects: Collaboration, Comprehensive Progarmmes and Community Coalitions: In Complex Society and Community Development Journal 35(2) 133-145

[2] Christernson, J.A. and Robinson, J.W. (1989) : Community Development in Perspective, Iowa State University Press, Ames Iowa [3] Denscombe, M. (2010)

[4] Flora, C.B. and Flora, J.L (1993) 'Entrepreneurial Social Infrastructure: A necessary Ingredient'. Annals of the American Academy Political and Social Sciences 539:48-58

[5] Gordon, W. and Frame, R.L (1995) : Real Hope in Chicago: The incredible story of how the Gospel is transforming a Chicago neighbourhood. Grand Rapids

[6] Michigan Zondervan Publishing House

[7] Gibon, P. Chachange, C,L.S.and Ericson, M. (2000) Mining and Structural Adjustment. Sweden Motala Grafiska

[8] Hasefeld, Y. (2010) Human Services as Complex Organisations, London, Sage Pulications.

[9] Hussey, R. and Hussey, J. (1997)

[10] Kanyenze, G. Kondo, T. Chitambara, P. And Martens, J (2011) Beyond the Enclave: Towards a Pro-Poor and Inclusive Development for Zimbabwe. Harare, Weaver Press. 
[11] Maphosa F (1997) Corporate Social Responsibility in Zimbabwe, in Zambezia

[12] University of Zimbabwe Press

[13] Maphosa F. (1998) The Human Factor and Corporate Social Responsibility

[14] in Zimbabwean Business organizations in Chivavura, V.G. and Mararike, C.G. (Eds) The Human Factor Approach to Development, University of Zimbabwe Publications 148-156

[15] Moyo, M. (1999) The Southern African Environment. London, Earth Scan Publications.

[16] Otto, J. (2000) Mining Texation in Developing Countries. Colorado, Colorade School of Mines

[17] Sachs, A. (2007) The Constitutional Principles Underpinning Black Economic Empowerment, in Visions of Black Economic Empowerment (eds) Marcus, G. Mangucu, X Shabane, K; and Hadland A. Johannesburg, Jacana Media (Pty) Ltd.

[18] Tan, A. (2009) Community Development Theory and Practice: Bridging the Divide between Micro and Macro levels of Social Work. A paper presented at NACSW Convention, Indianapolis, Inc.

[19] Tauyanago,B. Mpofu, TG. Muponda, ZM. Mutami, N. (2009) Total History of Southern Africa. Harare. Priority Projects Publishing

[20] Shaffer, R. Deller S, and Mardocciller (2004) Community Economics: Linking Theory and Practice. Ames Iowa, Blackwell Publishing Professional

[21] Zimbabwe Indigenisation and Empowerment Act (2007), Harare, Government Printers 